\title{
Realism in Donald Trump's Middle East Policy
}

\author{
Barjas Habbas ALkumeet ${ }^{1} \quad$ Rakez AL-Aroud $^{2} \quad$ Hani Mefleh O. Hamdon $^{3} \quad$ Rami Aljbour ${ }^{4}$ \\ 1.The Higher Council for Science \& Technology (Jordan)-almafraq \\ 2.Jordan- jordan \\ 3.1-Al al-Bayt University - jordan $\backslash$ almafraq \\ 4. Al-Balqa Applied University (Jordan)
}

\begin{abstract}
This study aims at understanding the realism theory in Trump's Middle East policy which is manifested in his election program for the presidency, his main promises of his election program and his implementation of these promises on the ground. The study uncovered the psychological factors that affected Trump's foreign policy toward the Middle East, and his economic mentality. One important constituent of Trump's policy is power. He used power to enhance the position of the United States of America in the world and to support its national interests through proposing the principle "America First". Moreover, Trump emphasizes on the promotion of USA's cultural values by promoting democratic values and human rights, and activating political participation through transparent democratic elections in all countries of the world. Even though Tramp focuses on these values in his speeches, they are considered secondary because he believes in America's interests. The study found out that Trump's strategy is based on the notion of power. Trump believes that the protection of other countries like the Gulf States is not free, but they have to pay money. He also insisted on restoring the position of the United States internationally by necessary force, especially in the Middle East. Based on these results, the study recommended that the use of excessive force would lead to a decline in USA's policy and reputation internationally.
\end{abstract}

Keywords: Middle East ; , Realism "Pay for protection" principle

DOI: $10.7176 / \mathrm{IAGS} / 85-02$

Publication date:August $31^{\text {st }} 2020$

\section{I- Introduction:}

When the United States emerged from its isolation and decided to get involved in international political and military issues, the Presidents of the United States issued a series of principles that constitute the policy of the United States of America. The content of these principles ranged from idealism to pragmatism in order to protect the national security of the United States of America. Since then the United States became the superpower in the world. The most important principles are: the Truman principle, the Eisenhower principle, the Carter principle, the principle of Reagan (Almasri, 2007, p. 67).

When Trump came to power, he proposed a new principle that governs international relations. The main feature of this principle is that Trump International's policy is economic in nature. Trump is seen by the whole world as a businessman, not a politician, which is revealed in his speech at the American Islamic Summit in Riyadh. The principle of "America First" was declared as a general goal of Trump's foreign policy. This principle means that USA interests must be respected and treated as a leading force for any move in international politics, and USA will no more protect other countries for free. (Ryan, 2016).

Trump's visits to the Middle East were considered as the beginning of the implementation of his new principle in the Middle East. He set a new stage in the history of international relations by building new alliances in the world. Trump started this visit by holding meetings with Arab and Islamic countries in Saudi Arabia, in which he stressed the need to work together to fight terrorist organizations and those who support them. (Keiswetter, 2018).

The policy of Trump in the Middle East cannot be explained at political level, rather it is economic one. What prove this suggestion are his deals with the Gulf countries in which he stressed on his principle 'America first' (Abu Karim, 2017, 11).

\subsection{Problem of the study}

The problem of the study came from the fact that the realism is best represented in Donald Trump's policy towards the Middle East. Trump is seen is the only president of the United States who carried out his election program. Trump belongs to the "realism school" by focusing on the concept of power and USA's national interest. Thus, he implemented his program in the Middle East as part of his theory of realism.

\subsection{Importance of the study:}

The present study is very important because it studies Trump's policy of realism in the Middle East which is very important to the foreign policy orientations of the American political decision-maker. This policy is not 
viewed just as a shift in American foreign policy, but a shift in international policy. Thus, it is important to study Trump's orientations to the Middle East because there are real changes in the world. The incident of the moving the American Embassy to Jerusalem was an example of the importance of the realistic trends in Trump's policy.

\subsection{Objectives of the study:}

The present study aims to:

1- Learn more about Trump's biography and its impact on his policies in the Middle East.

2. Identify Trump's election program and its application.

3 - Analysis Trump's notion of "pay for protection".

4 - Identify the most important political orientations towards the cases in the Middle East.

5. Evaluation of the Trump Electoral Program (2016-2018).

\subsection{Question of the study}

The study answers the following questions:

1. Does Trump's social, economic and psychological life affect his policies in the Middle East?

2. Does Trump want to be the first president of the United States to carry out his electoral program?

3. To what extent can Trump achieve his "pay for protection" principle?

4. Did Trump implement his electoral program (2016-2018)?

\subsection{Theoretical framework:}

Power is the backbone of the realism theory in international relations because is the center of international relations, and one of the most important tools used by the counties to achieve its interests. Therefore, the purpose of the country is to be strong and able to protect its entity, unity, territorial integrity and security which will only be achieved through having the power (Jihad, 2016).

Realism theory has been used in this research because Trump belongs to realism school which relies on the concept of power. This theory studies international relations through studying American principles risen between the First World War and the second. It was based on a set of theoretical doctrines which consider conflict is the origin of international relations and selfishness is the basis of human nature.

Mikhaveli, Hobbes and other thinkers of the school of realism emphasize on the selfish and aggressive nature of humankind. They also affirm that force is a decisive factor in human behavior. Therefore, a person always seeks to acquire more power. Thus, the strength in international relations also emphasizes the idea of power.

\subsection{The assumptions of realism theory}

The theory of realism was based on the following assumptions: (Burchill, 2001, 17-23).

1 -The country is the main player in international relations.

2-The country is seen as one unit in its dealings with the outside world

3-The alliances between countries increase the ability of the state to defend itself.

4- Realism sees human nature as fixed and unchangeable because man is evil in nature.

5-The geographic location of the State have an effect on its potentials and foreign political orientation.

6-Politics is not based on moral principles; thus, morality should be separated from politics.

7-Realistic theory stressed on the difficulty of achieving peace through international law or even the global government, so it is necessary to use force/power to achieve peace.

8-Morality and religion are not rational ideas because they are based on emotions and feelings (Booth,2011, 184).

Based on the principles of realism in USA foreign policy, there are four major trends in the United States: the first one is the realist trend which believes in power and lessens the importance of the domestic policies of foreign policy. The second one is the conservative movement that believes that the military force of the United States must be devoted to the dissemination of the value system of American society. The third trend emphasizes on the international position of the United States which imposes special responsibilities on international security. The fourth one does not trust the capacity of international institutions and international law (Stephen, 1998, 4-9).

Trump emphasized on enhancing USA power, protecting the interests of America, defending his strategic allies such as Israel, and applying the realism theory manifested in his principle "pay for protection". Therefore, Trump built his strategies on the power and preserving American interests in the world. Trump's main strategies include (EIlanm, 2017, 1):

1. Protecting USA land from weapons of mass destruction, extremist ideologies and growing military capabilities of hostile regimes. To counter these threats, the United States needs to deploy sophisticated missile defense systems.

2- Enhancing USA economic prosperity by protecting the innovation. 
3- Pursuing a policy of "peace by force" to deter a wide range of enemies, including rogue regimes such as Iran and North Korea, terrorist groups, criminal organizations, and rival forces such as Russia and China. This policy requires greater resources for the US military (Rodger, 2017, 5).

4- Increasing USA's power internationally through a number of competitive strategies, and enabling regional partners to be able to take firmer positions in the international arena (Nassif, 1991, p165).

Trump is interested very much in the Middle East in order to gain natural resources. Thus, his main concern is achieving America's interests by getting the oil, seeking its stability, cooperating with regimes in the Middle East to combat terrorism, promoting democracy, and supporting freedoms and human rights (Stephen, 2018, 5).

\subsection{The importance of the Middle East}

The Middle East is a term emerges after the Second World War to refer to the region from Turkey north to Yemen to the south and from Libya to the West to Iran in the east. This expression was first used in 1902 by an American naval officer (Alfred Mahan), pioneer of naval power theory. The importance of Middle East is as follows (Dalder, 2006, p9):

1- Middle East is the cradle of civilizations: many civilizations emerged in the Middle East such as the Mesopotamian civilization (Babylon, Assyria, Sumer, and the Nile civilization)

2. The religious aspect: The Middle East is the cradle of the three major religions (Judaism, Christianity and Islam). All the prophets revealed their messages in the Middle East between Egypt, Palestine, Iraq, Jordan, Najd and Hijaz.

3 - The economic aspect: The economic status of the Middle East is very importance is due the presence of oil which consists $66 \%$ of the world oil reserves. The Middle East has produced about a third of world oil production, and it is considered the main supplier of oil to the developed world, especially Europe, United States, Russia and Japan. Moreover, the Middle East is rich with precious metals, such as uranium, mercury, phosphate and gas. The Middle East is also considered one of the largest weapon markets. Countries of the Middle East spent a lot of money on wars and arms purchases. (AL-Hurmazy 2016, p248)

4- Strategic aspect: The Middle East is located in strategic position. Thus, various countries, such as USA, Russia, and Britain, which has a long history of colonization in the region.

\subsection{Trump's personal life}

\subsubsection{Trump's birth}

Donald Trump was born on June 14, 1946, the fourth son of a five-member family. His father is Fred Trump, a rich man and real estate owner in New York City. Donald was deeply influenced by his father which makes him work in his father's real estate development career. In 1968, Trump studied at Kew Forest in Forest Hills, Queens. At the age of 13, he joined the New York Military Academy, then enrolled at Fordham University for two years and then enrolled at the Wharton School of the University of Pennsylvania. In 1968, he received his BA in Financial Economy, and joined his father in Real Estate Company after graduation. When he hold office in his father's company, he changed his name to Trump and became one of the most famous businessmen in the United States of America in the US real estate sector.

\subsubsection{His marital life}

Trump married Ivana Trump from the Czech Republic in 1977 and had three children. He separated in 1992 and in 1993 he get married to Marla Maples, an American woman from Georgia, who separated from her in 1999. In 2004 he married Melania Kanoz of Slovenian origin, and gave birth to Baron, the fifth son of Trump (Issa, 2017, 2).

\subsubsection{His career}

He began his career as director of the Commodore Hotel in New York City. He also worked on different projects in the field of housing construction, then he worked in aviation industry in the name of Eastern Shtell. He then bought the Taj Mahal Casino from the Crosby family which led to the decline of the economic situation of Tramp. In the late nineties, his financial condition was improved; he bought the Trump Tower in 2001. He expanded his work in hotels so he became a famous businessman in the United States of America. In February of 2015, Forbes estimated Trump's fortune at $\$ 4$ billion ( Bou khreis, 2018).

\subsubsection{Trump's social life}

The social life of Trump was characterized by instability. Marring three women is a sign of his social and psychological instability. The repetitive marriage in psychology is a sign of his belief in absolute power, disintegration, hopelessness and frustration, and behavioral disorder. These qualities appeared when Trump takes his decision individually without consulting the US Parliament (Sharif, 2018, 2).

The analysis of the personality of US President Trump from the psychological point of view is not intended to abuse, but to know the impact of his behavior in childhood and youth on the nature of his political decisions, and the impact of these behaviors on the American people in particular and the world in general. The analysis is just a psychological assessment to determine to which these behaviors affect trump's decisions (Majdy, (2017). 
Many psychiatrists attempted to explain the psychological and mental state of US President Donald Trump. Analyzing Trump's behavior and speech, he was found to be paranoid, delusional, and separated from reality. Doctors have proved that Trump's speech about Mexico emphasizes his fear and concern for his personal image rather than public interest. Psychological analysis has also confirmed that Trump is arrogant, narcissistic who loves himself to the point of insanity (Rosemary, 2017).

The American Psychiatric Association confirmed that there are certain symptoms of narcissism. If this person is infected with five of them, this indicates that he is suffering of narcissism (CARROLL , 2017):

1-He exaggerates his importance, talent, achievements, and superiority over his peers.

$2-\mathrm{He}$ is always preoccupied with delusions about his unlimited success, strength, genius and beauty.

3-He believes that he is unique, and can only be understood by the elite.

4-He feel that he is always right.

5- He lacks empathy for others.

6- He is jealous of others and envies them.

7-He pretends to know every things.

These symptoms were noticed in trump from his interviews, his speeches, the tone of his voice, and his body language.

\subsubsection{Trump Personal Characteristics}

In the context of previous considerations and themes, it is important to emphasize that Trump's messages are characterized by a lack of clarity and containing a large number of contradictions. They are also offensive and lack diplomacy. The reasons for these qualities are (Yemen, 2016, 15):

1- Absence of political experience of Tramp.

2- The predominance of businessman personality on his attitudes and thinking; thus, he sees everything from the perspective of gain and loss.

3- Trump's messages are not accepted by American political elites, but they attract traditional US citizen.

4- The predominance of the propaganda on his speeches as it is clear in his speech at the conference organized by the AIPAC ( Azyah, 2017).

5- Trump's lack of political experience weakens his position against Clinton who has a long political history; so he adopts a speech that strengthens his position and shows himself against the current presidential tendencies. (Azyah, 2017, 11).

A set of psychological features were derived from Trump's life history, which will have a role in the mood and thinking of Trump and predict his own way of making decisions (Qasim, 2018):

1- He does not differentiate between reality and fiction: Trump suffers from mental instability, social antisocial antagonism, personality disorders, aggression, mental illusions, and narcissism.

2- $\mathrm{He}$ is able to overcome frustration. The majority of world expect trump to fail in the election. For example, 78 percent of respondents in 18 Arab countries expected Hillary to win, compared to 9 percent who expected Trump to win. However, he believed in himself and insisted on his winning.

3- Trump has the most frank character in the history of the US presidencies, but he has many ideas and fantasies which make his decisions unpredictable (Lili ,2018, 4).

4- He makes decisions quickly; for example, he made 50 executive decisions in the first week of his presidency.

5- He suffers from (Islam phobia). He prevented the entry of citizens of seven Muslim countries in order to protect USA security.

6- On the other hand, he carries constructive ideas towards the future of America, making him more economically occupied than any American president. The danger in his practice is that his economic ambitions are driving him to use them in politics (Eldar, 2017, 3).

From the perspective of sociologists and criminologist, Trump has since childhood suffered from psychological changes in his personality. He has drawn the attention of his elementary school colleagues to his intolerance, his lack of acknowledgment of his mistakes, and quick decisions. At the youth stage, Trump's behavior was described as narcissism, charisma and showmanship. He saw himself as the only one who has strong personality while others have weak personalities.

Trump reacted very quickly and imposed his ideas on others. One time Trump punched the music teacher in the pretext of teacher's ignorance. Trump personality was changed from a school rioter to a brawler in the military academy, to an arrogant narcissist, and finally to the president of the United States of America.

Psychological and social characteristics have influenced Trump's decisions in the Middle East. Psychological factors are therefore linked to Trump's political orientations in the Middle East. In order to achieve US foreign policy objectives, Trump's main principles can be found in his foreign policy which include (Suleiman, 2016, 15):

1- America First: Trump adopts in his foreign policy this principle which means that achieving the interests of America is the only priority of USA policy, so America cannot protect any country without paying money for 
protection.

2- The principle of isolation in foreign policy: Trump sees that the United States of America should not interfere in the affairs of the world unless it serves the interests of USA.

3- Human intervention: Trump does not believe in the idea of humanitarian intervention for fear of involvement of the USA armed forces in a cause that does not serve American interests.

4- Migration policies: Trump sees migration as a threat to the USA economy, so he attempts to reduce immigration rates until it stops.

\subsection{Trump frames of US foreign policy toward the Middle East}

There are a number of internal and external forms that constitute a framework for President Trump's policy towards the Middle East, which can be illustrated as follows:

\subsubsection{Internal frames:}

1-The institutionalization of decision-making in American foreign policy. Even though Trump is the present of the USA, he does not form the foreign policy. The decision-making process of US foreign policy is a product of the interaction between US institutions, including the president, the foreign and defense ministries, Congress, pressure groups, and research centers.

2-Isolation trend in American politics: Trump adopts the policy of constructive isolation and the principle of "America First" which pave the way for a major shift in US foreign policy similar to the former President Monroe's policy in 1821. Isolation policy was based on activating available resources, whether natural or technological, to rebuild the United States as a major player in the international system.

3-Economic problems in the United States of America: these problems have caused many internal problems which are related to migration, unemployment capital flight, and violence in many US cities. These issues make American voters prefer Trump over other presidents (Katie, 2016, 2).

4- Trump's notion of Deal. Trump believes that USA's allies especially Gulf countries should pay for their protection or security. He is dealing with political issues as economic deals ( Schake, 2018, 12).

5-The primacy of realistic theory on Trump's policy: trump belongs to the Republican Party which believes in realism to achieve the interests of America; thus, they always resort to military intervention, the use of power, and sanction. On the contrary, the Democratic Party believes in idealism so they prefer using diplomacy, soft- power, negotiations, and humanitarian aid (Ivan, 2016).

According to the previous points, it appears that Trump policies focus on providing the best for the American people, especially at the economic levels. He also believes in restoring the dominant role of America and protecting its interests through military intervention at the expense of the countries of the Middle East.

\subsubsection{External frames:}

A number of external frames was identified in Trump's policy as follows (Haas, 2016):

1. Achieving American interests in the Middle East: There are constant interests of the United States in the Middle East, such as protecting Israel's security, ensuring cheap oil access, defeating terrorism, creating alliance with friendly and moderate countries. Thus, Trump's policy aims to find mechanism to preserve those interests. Trump found the Middle East as suitable environment to achieve these interests because the Middle East suffers from political crises. It is worth noting that Middle East will remain one of the priorities of foreign policy of USA because of the increasing role of Russia which may affect negatively the roles and interests of the United States ( Daniel ,2016)

2. The emergence of new players in the Middle East: Russia and Iran get involved in different issues of the Middle East, such as the Syrian crisis, the outbreak of Arab revolutions and the outbreak civil wars in many countries like Yemen, Libya, and Iraq. The rise of Russia and Iran is a result of the bad policy of Obama's administration in the Middle East ( Stronski, 2017, 3-4).

3. Policy of convergence with international players: The rise of new forces in the region represented in Russia, Turkey, and Iran has made Trump to cooperate with international players when dealing with crises and issues of the region. These conditions imposed on the US administration to build alliances with Russia, Turkey, Iran, Saudi Arabia and Egypt (John ,2016).

\subsection{Trump Theory's "pay for protection"}

Trump's foreign policy assures that USA will not provide military protection for any country if they do not pay. Trump has always stressed in many occasions that the Arab countries like Saudi Arabia should pay for their security. He pointed out that the poorest person in Kuwait lives the lives of kings, and they do not pay for their security. He believes that these countries should pay 25 percent of their income. Unlike the previous wars that has cost the United States billions of dollars, Trump states that USA will not wage wars for free. (Ieff, 2018)

Trump stressed in his campaigns in 2016 the necessity of Gulf States to pay, and this scenario was one of the main principles in his program. Trump also announced that public debt of USA is 19 trillion dollars and he promised to make the Gulf States pay the money. ( Stephanie, 2017) 
During Trump's historic trip to Saudi Arabia in May 2017, Trump signed an arms sale agreement with King Salman worth \$ 350 billion. In addition, US companies signed billions of dollars with other Gulf States such as the UAE, Kuwait, Bahrain and Qatar (Mvthili, 2017).

Trump pointed out the importance of USA military presence in the Gulf States because the Gulf States need protection from their neighbors or their people. He pointed out that without the existence of a US base in Qatar, it will be swept from the first day of the crisis in 2017. Trump stresses that the US military presence in the Gulf is not intended to protect these systems; it is to protect American interests in the Middle East, such as protecting the oil sources, maritime transport routes, and ensuring Israel's security (Al Jazeera Centre for Studies, 2017).

\subsubsection{Did Trump achieve his election program?}

In Trump's speeches, interviews and announcements, he stressed on achieving the following goals ( Beauchamp, 2018):

1. Abolition of the Iranian nuclear deal: Trump confirmed that his first priority as a president of America would be the abolition of the nuclear agreement between Iran and the major powers. Trump fulfilled this promise because he imposed economic sanctions on Iran.

2. Abolishing of Obama's health system: Obama's health system is one of the best health systems for the American people because it provides insurance for people over the age of 65 , people with special needs, Poor people, and low-income workers. This system assures that rich people should pay for health care through the collection of the taxes. Trump has promised to abolish Obama's Health system, leaving millions of Americans without health insurance. Trump could not cancel it because it became a national case. ( KIMBERL,2018)

3. Canceling travel visas for some countries: Trump's anti-immigration strategy threatened some countries to cancel US visa programs if they refused to withdraw their illegal refugees in the United States. The White House has announced new conditions to be met by citizens of six Muslim-majority countries, including having strong family or commercial ties in the United States in order to obtain visas. Trump made one of his biggest victories during his presidency in favor of his decision to ban the entry of citizens of several Muslim countries to the United States. However, the court found Trump's decision consistent with the scope of presidential powers under the US Immigration law (Clark,2018).

4. Deporting millions of Americans: Trump said in his election program that in his first days at the White House he would deport millions of illegal immigrants, impose huge restrictions on immigration laws, and chase and deport 2 million criminals in USA. However, his plan does not work because of public pressure and the humanitarian and social problems of the United States of America. For example, the mayor of New York, Seattle, Los Angeles and Chicago also announced their refusal to carry out any deportations planned by the Trump administration in their cities (Anthony, 2017).

5. Building US-Mexico wall: trump promised the American people to build a wall between America and Mexico to prevent illegal immigrants from entering America. He also said that Mexico should pay the cost of building the wall. The four-year wall, which costs more than $\$ 10$ billion, has been launched, but Mexico has insisted it will not pay (Rozina, 2018).

6. Defeating Islamic State in Iraq and Syria (ISIS): Trump said that upon his arrival at the White House he will ask his administration to prepare a plan within 30 days to eliminate ISIS. Trump achieved his goal of eliminating the terrorist organization in Iraq and Syria, declaring in 2017 that the United States had achieved victory over ISIS ( Robin, 2018).

7. Re-position of America in international forums: Although Trump did not explain the way to restore the role of America again in the world, but Trump made it a slogan of his campaign. US Vice President Mike Pines announced that President Trump's moves on the issues of Syria, Iran, North Korea and ISIS were steps taken to enhance the power and authority of the United States. He stressed that President Trump defends USA allies and fighting its enemies. (Peter, 2018).

8. Moving of the US Embassy in Israel to Jerusalem: the movement of the US Embassy from Tel Aviv to Jerusalem dates back to the time of President George W. Bush, but it was not succeeded. In addition, President Obama refused to move the embassy. Trump achieved his promise by moving the US Embassy from Tel Aviv to Jerusalem on 13 May 2018.

Trump has done $75 \%$ of his election program except Obama's health care program because he could not find a better alternative. In addition, he failed to deport millions of American immigrants because of the refusal of US judiciary. (Miriam, 2017)

\subsubsection{Trump and "the Deal of the century"}

The deal of the century, which emerged since Trump US presidency, is a new American vision to settle the Palestinian cause that deals with all major issues including Jerusalem, borders and refugees. Trump started to promote for this deal through mas media and counselling some countries such as Saudi Arabia, Egypt, Jordan and Israel.

According to media leaks, "the deal of the century" includes (Mohammed, A.2018, 8).

1- Establishment of a Palestinian state which includes Gaza Strip, Areas A and B, and parts of Area C in 
the West Bank.

2- Donor countries provide $\$ 10$ billion for the establishment of a state whose infrastructure will include an airport and a seaport in Gaza, housing projects, agricultural projects, industrial zones and new cities.

3- Postponing the status of Jerusalem and the case of refugees to subsequent negotiations.

4- Renouncing of a two-state solution and moving towards the files of Jerusalem, refugees and settlements, and proposing regional peace in the face of Iran.

5- The deal rejects any sovereignty over the Mediterranean region except Israeli sovereignty and reassures that Jerusalem is the only capital of Israel.

The reactions towards "the deal of the century" can be summarized as follows:

1. Palestine: The Palestinians feel pessimistic about the deal of the century because it is not for their interest. It is considered as a conspiracy cause it recognizes Jerusalem as the capital of Israel, affirms the annexation of the major illegal settlements in the West Bank to Israel, and declares Palestine as demilitarized state (Jack, 2018)

2. Egypt: even though Egypt benefits from the deal, the Egyptian President al-Sisi declared that he is not enthusiastic to the deal because he rejects separating the Gaza Strip from the Palestinian territories and leaving it to Hamas (Jonathan, 2018)

3. Jordan: The King of Jordan, Abdullah II, rejected the idea of the deal, calling it an Israeli-American plan that would lead to the withdrawal of Jordan's supervision of the Holy Places in Jerusalem for Saudi Arabia, and establishing Confederacy between Jordan and Palestine (France 24, 2018 )

4. Trump's vision: Trump sees the deal as one of the paths of peace between Palestine and Israel which will settle the conflict between the two sides by recognizing the two states. According to Trump, it is an opportunity for the Palestinians to have a Palestinian state recognized by the United Nations. In addition, he states that America will be the first Western country to recognize the "Palestinian state", but at the same time the Palestinians should admit on the right of Israel's establishment of settlement blocs (Marwan, 2018, 11 ).

\section{II- Conclusion and recommendations \\ - Conclusion}

The following conclusions can be drawn from the study:

1- The study proved that Trump's policy is based on realism. Trump focused on re-positioning the United States of America internationally through the use of force to fulfill America's strategic interests, especially in the Middle East.

2- The study proved that there is a relationship between Trump's behavior in his personal life and his policy as President of the United States of America.

3- The study proved that Trump is the best American president who has carried out his electoral program in America's history.

4- The study showed that power is one of Trump ways to achieve the interests of America. He used the theory of "pay for the protection" to get money from the Gulf countries, especially Saudi Arabia.

5- The study confirmed that Trump was able to apply his principle "USA first", which makes him a very popular president.

6- The study proved that "the deal of the century" led to a decline in relations between the Arab countries and America.

7- The study showed that moving the US Embassy from Tel Aviv to Jerusalem would lead to the loss of Trump's alliance with some Arab leaders.

\section{Recommendations of the study}

1- The study recommended that Trump should adopt the ideal theory that emphasizes on international ethics and the dissemination of democratic values and human rights.

2 - The study recommended that the use of excessive force will reduce the reputation of Trump regionally and internationally.

3 - The study recommended that Trump should withdraw "the deal of the century" because it would lead to conflict between Palestine and Israel, leading to the deterioration of US-Arab relations.

4 - The study recommended that Trump should minimize Israel's role in the Middle East because it would lead to instability in the Middle East.

5 - The study recommended that Trump should suspend uranium enrichment within Iran's nuclear program because it threatens the Gulf States and the Arab states.

6 - The study recommended that the Trump should respect the sanctity of Al-Aqsa Mosque and it should remain under the guardianship of the Hashemites, keeping in mind that the Holy Places are part of the Hashemite and Islamic heritage. 
References

Abu Karim , Mansour (2017), “Trump Principle in International Relations”, Egypt: Democratic Arabic Center.

Al Jazeera Centre for Studies (2017), “The 'Berlin Wall' has not broken the will of the Qataris, Qatar: Al Jazeera Centre for Studies.

AL-Hurmazy, Sword. (2016), "The Approaches of American Smart Power as a Mechanism of International Change ", Qatar: Arab Center for Research and Policy Studies.

Anthony, Zurcher (2017) “Has Trump kept his campaign promises?" retrieved from https://www.bbc.com/news/world-us-canada

Azyah, Abdul Kareem (2017). “Trump mentality. First-class businessman”, Qatar: Al-Jazeera Center for Studies.

Beauchamp ,Zack (2018) Trump's withdrawal from the Iran nuclear deal, explained, vox media ,may ,22,USA.

Booth, ken (2011) "realism and world politics", London: Routledge

Bou khreis, Ahmed (2018) "Readings in the Trump Economic Wars", Berlin: Arab Democratic Center.

Burchill, S. et. al. (2001). "Theories of International Relations", 2nd edition. New York: Palgrave Macmillan retrieved from

http://lib.jnu.ac.in/sites/default/files/RefrenceFile/Theories-of-IR 0.pdf

Carroll ,Y (2017) . "Fact-checking Trump's interview about first 100 days", retrieved from https://www.miamiherald.com/news/

Clark, Mindock (2018) “Trump's travel ban on six Muslim-majority countries to be fully enacted after Supreme Court ruling", retrieved from

ww.independent.co.uk/news/world/americas/us-politics/trump-travel-ban-muslim-countries-supreme-courtruling-allowed-go

Dalder, Ivo (2006). "American-European strategy towards the Greater Middle East." Lebanon: Arab Science House Publishers.

Daniel, byman (2016) "Shifting U.S. interests in the Middle Eas"t, retrieved from www.brookings.edu

EIlanm, Perman,(2017) "New Trump Strategy .. What Does the Middle East Mean" Middle East Broadcasting, Network. Retrieved from

http://www.ilanberman.com/20674/what-trump-new-strategy-means-for-the-middle-east

El Masri .Ahmed ( 2007) “American Strategy and the Middle East: Theoretical Logic and Practical Applications", Journal of Arab Strategic Thought (3).

Eldar, Sarajlic (2017) "Donald Trump And The American Dream", HuffPost News, Nov 22 ,USA

France 24 ( 2018 ) "Jordan rejects idea of confederation with Palestinians",sep,5.

Haas ,Richard N,( 2016) "America and the World in Transition, Project Syndicate”, Qatar: Al Jazeera Center for Studies.

Ibrahim, Abdel-Amir Abdel-Hassan (2009). "The Realistic Approach and its Impact on American Foreign Policy", Master Thesis, Faculty of Political Science, University of Baghdad.

Ieff, Cox (2018) "Trump has set economic growth on fire. Here is how he did it" retrieved https://www.cnbc.com/2018/09/07/how-trump-has-set-economic-growth-on-fire.html

Issa, Rola (2017). "The first wife of President Trump issues a new book on his three marriages", Morocco Today's News website, October 10, Morocco.

Ivan, Eland (2016) "Trump's foreign policy is the realism America needs", New York post. Retrieved from : http://nypost.com/2016/04/29/trumps-foreign-policy

Jack, Khory (2018) "Palestinians to U.S.: No 'Deal of the Century' if Jerusalem Not Addressed", Haaretz newspaper, www.haaretz.com/us-news/palestinians-to-u-s-no-deal-of-the-century-without-jerusalem

Jihad, Mahmoud Abdel-Mohdi (2016). “The Concept of Strength in International Politics", Alternative Website, 18, October, Egypt.

John ,Esposito (2016). "Trump: Politics of Solitude and the Edge of Abyss", in an interview with Sky News Arabia, November 20, UAE.

Jonathan, Cook (2018) "What's in Trump's 'deal of the century'? The answers are in plain sight middle east eyes" , Jun , 15 England

Katie, Allen (2016) "Trump's economic policies: protectionism, low taxes and coal mines", retrieved from https://www.theguardian.com/us-news/2016/nov/09/trumps-economic-policies-protectionism-low-taxesand-coal-mines

Keiswetter ,Allen L. 2018) ) “Trump's national security strategy: implications for the Middle East" , Washington :The Middle East Institute.

Kimberl, Amadeo (2018) "Donald Trump on Health Care" retrieved from /www.thebalance.com, Nov, 22

Lili ,Loofbourow(2018) “How the reality of Trump's America outpaced House of Cards?" Guardian 
newspaper. Retrieved from https:/www.theguardian.com/tv-and-radio/2016/mar/16/donald-trump-houseof-cards-frank-underwood-election-2016

Majdy, Zahra (2017). “Is Trump mentally ill? Psychology Answers", Retrieved from https://www.sasapost.com/is-trump-psycho/

Marwan, Bishara ( 2018 ) "Trump and Palestine: Shock of the century": Qatar: Al Jazeera Center for Studies.

Miriam , Yalvede (2017) Move U.S. Embassy in Tel Aviv to Jerusalem, retrieved from www.politifact.com/truth-meter/promises/trumpometer/promise/1377/move-us-embassy-tel-aviv-jerusalem

Mohammed, Amin (2018). "The Deal of the Century .. Thus Trump sees the solution of the Palestinian issue", Al Jazeera Center for Studies, February 4, Qatar

Mvthili, Sampathkumar (2017 ) Donald Trump to announce \$350bn arms deal with Saudi Arabia - one of the largest in history, retrieved from

www.independent.co.uk/news/world/americas/us-politics/trump-saudi-arabia-arms-deal-sale-arab-nato-gulfstates

Nassif, Yousef hatty (1991) "the Arab regional system", Beirut: Global system Center for Arab Unity Studies.

Qasim, H, Saleh (2018).”Trump character.. Psychological analysis”, Journal of the intellectual. http://www.ahewar.org/debat/show.

Robin, simox (2018) Did Trump Really Beat ISIS the National interest?. Retrieved from nationalinterest.org/feature/did-trump-really-beat-isis

Rodger, Baker (2017) Understanding America's Global Role in the Age of Trump. Retrieved from https://worldview.stratfor.com/article/understanding-americas-global-role-age-trump

Rozina, Sabur (2018) What has happened to each of Donald Trump's campaign pledges?jan ,21, washington, /www.telegraph.co.uk

RYAN, TEAGUE BECKWITH (2016) Read Donald Trump's 'America First' Foreign Policy Speech, Time Inc, retrieved from

http://time.com/4309786/read-donald-trumps-america-first-foreign-policy

Schake ,Kori, (2018) The Trump Doctrine Is Winning and the World Is Losing, the new York times , retrieved from https://www.nytimes.com/2018/06/15/opinion/sunday/trump-china-america-first.html

Sharif, Mahdi (2018). Far from the presidency .. «Trump» lifestyle, Emirates newspaper today, September 28, the United Arab Emirates.

Stephanie, Kirchgaessner ( 2017) Qatar diplomatic crisis: what are Trump's financial links to the region? The guardian ,jun,23,

Stephen .M .Walt (1998) International relations: One world, many theories Foreign Policy. Retrieved from

https://edisciplinas.usp.br/pluginfile.php/4018694/mod_resource/content/1/Walt\%201998.pdf

Stephen, Zunes (2018) Trump's Middle East Policy: The Ironies of Hawkishness, Qatar: Al Jazeera Center for Studies.

Stronski, Paul \& Sokolsky, Richard (2017). The Return of Global Russia: An Analytical Framework. Washington: Carnegie Endowment for International Peace Paper, pp. 3-4

Suleiman, Yamani (2016). Foreign Policy Directions at Donald Trump, Egyptian Institute for Political and Strategic Studies, Cairo, Egypt. 